\title{
Exquisite Regioselectivity and Increased Transesterification Activity of an Immobilized Bacillus subtilis Protease
}

\author{
Lino Ferreira,† M. A. Ramos,‡ Maria Helena Gil, ${ }^{\dagger}$ and J onathan S. Dordick*,§
}

Departamento de Engenharia Quimica, Universidade de Coimbra, Pinhal de Marrocos, 3030 Coimbra, Portugal, Instituto Superior de Engenharia, Inst. Politecnico de Coimbra, 3000 Coimbra, Portugal, and Department of Chemical Engineering, Rensselaer Polytechnic Institute, 102 Ricketts Bldg., Troy, New York 12180

\begin{abstract}
Commercially available proteases and lipases were screened for their ability to acylate regioselectively sucrose with divinyladipate either in pyridine or dimethylformamide (DMF). The protease (EC 3.4.21.62) from Bacillus subtilis (Proleather FG-F) exhibited the highest conversion (100\% in $24 \mathrm{~h}$ of reaction in DMF) yielding sucrose $2-0$ vinyladipate as main product. The enzyme preference for a secondary hydroxyl group is a distinct feature of this biocatalyst compared to others described in the literature. Two sets of chemically distinct silica supports were used for Proleather immobilization presenting terminal amino $\left(\mathrm{S}_{\text {APTES }}\right)$ or hydroxyl groups $\left(\mathrm{S}_{\text {TESPM-PHEMA }}\right)$. The percentage of immobilized enzyme was smaller in SAPTES (7-17\%) than in STESPM-pHema $(52-$ $56 \%$ ), yet Proleather immobilized into S SPTES supports presented higher total and specific hydrolytic activity. The highest total and specific activities were obtained with STESPM-pHEMA and SAPTES, respectively. Silicas with large pore (bimodal distribution of pores, $130 / 1200 \AA$, denoted as $S_{1000}$ ) presented higher specific activities relative to those with smaller pore sizes. Furthermore, the synthetic specific activity of $\mathrm{S}_{1000} \mathrm{~S}_{\text {APTES }}$ immobilized protease was ca. 10-fold higher than that of the free enzyme. In addition to sucrose, the immobilized protease was used to acylate methyl $\alpha$-D-glucopyranoside, trehalose, and maltose in nearly anhydrous DMF. Finally, immobilized Proleather was reasonably stable, retaining ca. 55\% activity after six reaction cycles.
\end{abstract}

\section{Introduction}

Recently there has been an increasing interest in the use of renewable resources as organic raw materials and in particular the use of carbohydrates for the preparation of polymers (1). End uses of these synthetic sugarcontaining materials include thickeners, flocculating agents, polymeric detergents, surface modifiers for synthetic polymers, and cross-linked for the preparation of water-swellable gels $(2,3)$. The functionalization of sugars with vinyl groups is a useful reaction to yield chemically polymerizable moieties and efficient high molecular weight polymers. Regioselective acylation, now a hallmark of nonaqueous biocatalysis, offers a highly efficient approach to vinyl functionalization of sugars when compared to conventional chemical synthesis, which relies on multistep blocking/deblocking $(1,4)$.

In our previous work, we used several enzymatic strategies in nonaqueous media to incorporate vinyl groups into sugars (5-9); however, little effort was devoted to designing these reaction systems for largerscale biotransformations. In particular, immobilized enzymes offer specific advantages in process scale-up, including ease of handling and recovery/reuse, and in providing an active and stable matrix for enzyme function in organic media (10-13).

* To whom correspondence should be addressed. Ph: 518-2762899. Fax: 518-276-2207. Email: dordick@rpi.edu.

† Universidade de Coimbra.

₹ Inst. Politecnico de Coimbra.

$\S$ Rensselaer Polytechnic Institute.
This work describes the preparation of vinyl sugar derivatives using a protease from Bacillus subtilis, onto well-characterized silica supports. These supports were chosen mainly because of their mechanical and physical characteristics, in particular their hardness, incompressibility, and high controlled surface area, which make them especially suitable to be used in packed or fluidized bed reactors (14). A correlation of the catalytic performance by free and immobilized enzyme is presented. The ester synthesis activity of the immobilized enzyme was ca. 10-fold higher than that of the free form. Furthermore, immobilized Proleather was reasonably stable, retaining ca. 55\% activity after six reaction cycles.

\section{Materials and Methods}

Materials. The two porous silicas used in this work were supplied by Macherey-Nagel (Duren, Germany) specified by the manufacturer as Nucleosil $300\left(\mathrm{~S}_{300}\right)$ and Nucleosil $1000\left(\mathrm{~S}_{1000}\right)$. 3-(Trimethoxysilyl)propyl methacrylate $\left(\mathrm{S}_{\text {TESPM }}\right)$, 3-aminopropyl)triethoxysilane $\left(\mathrm{S}_{\text {APTES }}\right)$, and 2-hydroxyethyl methacrylate (HEMA) were purchased from Aldrich (Bornem, Bel gium). Glutaral dehyde (25\%), 1,1'-carbonyl diimidazole (CDI ), N-trans-cinnamoylimidazole, methyl $\alpha$-D-glucopyranoside, sucrose, $D(+)$ trehalose dihydrate, and trimethylsilyl (TMS) reagent (Sigma Sil-A) were obtained from Sigma Chemical Co. (St. Louis, MO). Sodium cyanoborohydride (95\%) was purchased from Aldrich (Milwaukee, WI), and $\mathrm{D}(+)$ maltose monohydrate and casein $\left(M_{w}\right.$ of $\left.30,000 \mathrm{Da}\right)$ were purchased from Fluka AG (Buchs, Switzerland). Divinyladipate (DVA) was purchased from TCl America (Portland, OR). The protease (EC 3.4.21.62) from Bacillus 
Table 1. Enzyme Screening for Transesterification Reaction of Sucrose with DVA

\begin{tabular}{|c|c|c|c|c|}
\hline \multirow[b]{2}{*}{ entry } & \multirow[b]{2}{*}{ enzyme } & \multirow[b]{2}{*}{ origin } & \multicolumn{2}{|c|}{ conversion (\%) $^{d}$} \\
\hline & & & pyridine & $\overline{D_{M F}}$ \\
\hline 1 & Proleather FG-Fa & Bacillus subtilis & 27.8 & 100.0 \\
\hline 2 & Protease $A^{a}$ & Aspergillus oryzae & 0.0 & 1.6 \\
\hline 3 & Protease $\mathrm{N}^{\mathrm{a}}$ & Bacillus subtilis & 1.2 & 0.7 \\
\hline 4 & Protease $\mathrm{Pa}$ & Aspergillus melleus & 1.5 & 19.1 \\
\hline 5 & Protease $\mathrm{S}^{\mathrm{a}}$ & Bacillus stearothermophilos & 2.7 & 0.0 \\
\hline 6 & Protease Subtilisin Carlsbergb & Bacillus licheniformis & 47.8 & 28.2 \\
\hline 7 & Lipase $A^{a}$ & Aspergillus niger & 3.0 & 20.3 \\
\hline 8 & Lipase AYa & Candida rugosa & 4.1 & 62.1 \\
\hline 9 & Lipase Ma & Mucor javanicus & 2.3 & 38.5 \\
\hline 10 & Lipase PSa & Pseudomonas cepacia & 3.5 & 83.0 \\
\hline 11 & Lipase porcine pancreas $^{b}$ & porcine pancreas & $n r^{f}$ & $\mathrm{nr}$ \\
\hline 12 & Lipase Candida antarticac & Candida antartica & $\mathrm{nr}$ & 8.7 \\
\hline
\end{tabular}

a Supplier: Amano. b Supplier: Sigma. ' Supplier: Novo Nordisk. ${ }^{\mathrm{d}}$ Conversion, as determined by GC, for a reaction time of $24 \mathrm{~h}$. ${ }^{\mathrm{I}} \mathrm{In}$ the absence of enzyme the conversion was $8.1 \%$ (reaction time of $24 \mathrm{~h}$ ). ${ }^{\mathrm{f}} \mathrm{nr}=$ no reaction detected.

subtilis (Proleather FG-F) was a gift from Amano Enzyme Ltd. (Troy, VA). The other enzymes used in this work were commercially available, and the suppliers, as well as their respective origins, are described in Table 1. Solvents were dried over mol ecular sieves for at least 24 $\mathrm{h}$ prior to use to remove residual water. The water content in DMF was measured by Karl Fischer titration and was $0.06 \%(v / v)$. Other chemicals and solvents were of the highest grade commercially available.

Analytical Methods. Qualitative analysis of sugar esters was performed by thin-layer chromatography (TLC) on aluminum precoated plates (silica gel $60, \mathrm{~F}_{254}$, Merck) with an eluant consisting of ethyl acetate/ methanol/water (17:4:1, v/v) and detection via charring with ethanol/anisaldeyde/ $\mathrm{H}_{2} \mathrm{SO}_{4}$ (18:1:1, v/v/v) solution and heating at $100{ }^{\circ} \mathrm{C}$. Quantitative analysis of sugars and sugar derivatives was performed by gas chromatography (Shimadzu GC-17A) with an AOT (Restek Corporation Bellefonte, $\mathrm{PA}$ ) capillary column (30 m, $0.25 \mathrm{~mm}$ i.d., and $0.25 \mu \mathrm{m}$ film thickness) and $\mathrm{He}$ as the carrier gas. The injector and detector temperatures were set at $250{ }^{\circ} \mathrm{C}$. The column temperature was maintained at 140 ${ }^{\circ} \mathrm{C}$ for $2 \mathrm{~min}$, ramped at a rate of $10{ }^{\circ} \mathrm{C}$ to $325^{\circ} \mathrm{C}$, and then held for $10 \mathrm{~min}$. Prior to GC analysis samples were derivatized with a TMS reagent (Sigma Sil-A).

${ }^{1} \mathrm{H}$ and ${ }^{13} \mathrm{C}$ NMR spectra were recorded on a Varian Unity spectrometer (Palo Alto, CA) at 499.84 and 125.70 $\mathrm{MHz}$, respectively. ${ }^{1} \mathrm{H}$ NMR spectra were recorded in $\mathrm{D}_{2} \mathrm{O}$ (60-100 mg in $0.7 \mathrm{~mL}$ ) using a pulse angle of $90^{\circ}$ and a relaxation delay of $20 \mathrm{~s}$. The water signal, used as reference line, was set at $\delta 4.75 \mathrm{ppm}$ and was suppressed by irradiation during the relaxation delay. The number of scans in the spectra acquisition was $8 .{ }^{13} \mathrm{C} N M R$ spectra were recorded in $\mathrm{D}_{2} \mathrm{O}$ using a pulse of $30^{\circ}$ and relaxation delay of $11.5 \mathrm{~s}$. tert-Butyl alcohol was used as reference line and set at $\delta 31.2$ ppm versus tetramethylsilane. The number of scans in the spectra acquisition was 128.

Functionalization and Chemicophysical Characterization of Silica Supports. Two methods were used for the modification of silicas. In the first method, the silicas were silanized with $\mathrm{S}_{\text {APTES }}$ and $\mathrm{S}_{\text {TESPM }}$ according to the methodology reported by Ramos et al. (14). Briefly, the silicas were suspended in toluene $(20 \%$, w/v) under nitrogen atmosphere and treated in a $5 \%(\mathrm{v} / \mathrm{v})$ solution of silane compound/toluene. The suspensions were refluxed for $2 \mathrm{~h}$. Finally, the functionalized silicas were allowed to cool to room temperature, filtered, washed three times with toluene, rinsed with methanol, and dried at $60^{\circ} \mathrm{C}$ overnight.

In the second method, the modified silicas containing vinyl groups were grafted with HEMA by X-ray irradia- tion, using a $15 \mathrm{MeV} 20 \mathrm{KW}$ linear el ectron accelerator. In all experiments, $1 \mathrm{~g}$ of silica was suspended in $10 \mathrm{~mL}$ of methanol containing 0.822 M HEMA and the mixture was irradiated at $0.95 \mathrm{~Gy} \mathrm{~s}^{-1}$ for $16 \mathrm{~h}$ at room temperature in the presence of air. After irradiation, the silica was filtered and extensively washed with methanol, extracted with methanol using a Soxhlet apparatus during $6 \mathrm{~h}$, and dried at $70{ }^{\circ} \mathrm{C}$ under reduced pressure until constant weight was achieved. Silicas were characterized regarding particle size, surface area, mean pore diameter, true density, porosity, yield of grafting, and water vapor sorption, as previously described (14). The silanized samples are designated by $\mathrm{S}_{x} \mathrm{~S}_{y}$, where $\mathrm{S}_{x}$ denotes the original silica $\left(S_{300}\right.$ or $\left.S_{1000}\right)$ and $S_{y}$ specifies the silane compound used ( $\mathrm{S}_{\text {TESPM }}$ or $\left.\mathrm{S}_{\text {APTES }}\right)$. The methacrylated silicas grafted with HEMA were denoted by $\mathrm{S}_{\mathrm{X}} \mathrm{S}_{\text {TESPM-pHEMA. }}$

Methods of Immobilization. Immobilization on Sx $\mathbf{S}_{\text {APTES }}$ Supports. Glutaraldehyde was used as the activating agent for the coupling of the enzyme to amine groups of the modified silicas. Two immobilization protocols were used regarding the application of the immobilized enzyme in aqueous solution (protocol $A$ ) or organic medium (protocol B). In protocol A, $50 \mathrm{mg}$ of the $\mathrm{S}_{\mathrm{X}} \mathrm{S}_{\text {APTES}}$-silica was added to $4.9 \mathrm{~mL}$ of $0.1 \mathrm{M}$ phosphate buffer $\mathrm{pH} 8.0$ and $0.1 \mathrm{~mL}$ of glutaraldehyde solution $(25 \%, v / v)$. Support activation was carried out at $25^{\circ} \mathrm{C}$, without stirring, for $15 \mathrm{~min}$. The activated silicas were then removed by filtration and thoroughly rinsed with distilled water $(3 \times 10 \mathrm{~mL})$. Enzyme solutions $(0.1 \mathrm{~mL}$, $80 \mathrm{mg}$ of Proleather per $\mathrm{mL}$ ) in $0.1 \mathrm{M}$ phosphate buffer $\mathrm{pH} 8.0$ were added to $4.9 \mathrm{~mL}$ of the same buffer with the activated support. Sodium cyanoborohydride reduction was performed to convert unstable Schiff's bases into stable secondary amines. Hence, $80 \mu \mathrm{L}$ of an aqueous solution of sodium cyanoborohydride, $0.08 \%$ (w/v) in 0.1 $\mathrm{M}$ phosphate buffer $\mathrm{pH}$ 8.0, which represented an excess, was added $30 \mathrm{~min}$ after addition of enzyme solution. The coupling reactions were performed over $18 \mathrm{~h}$ at $25^{\circ} \mathrm{C}$ without stirring, after which the solids were filtered and rinsed with $0.1 \mathrm{M}$ Tris- $\mathrm{HCl}$ buffer $\mathrm{pH} 8.5$ until the filtrate was totally free of protein (determined by the Sedmak method, see below). At this point, it was assumed that the protein that was not removed was either covalently bound or physically entrapped within the silica matrix. All washing solutions were analyzed for protein using the Sedmak method (see below), and the activity of immobilized enzymes were determined using casein as the substrate (see below).

In protocol $\mathrm{B}, 600 \mathrm{mg}$ of the $\mathrm{S}_{\mathrm{X}} \mathrm{S}_{\mathrm{APTES}}$-silica was added to $39.0 \mathrm{~mL}$ of $0.1 \mathrm{M}$ phosphate buffer $\mathrm{pH} 8.0$ and $0.8 \mathrm{~mL}$ of glutaral dehyde sol ution (25\%, v/v). Support activation 
was carried out at $25^{\circ} \mathrm{C}$ with orbital shaking (90 rpm) for $15 \mathrm{~min}$. The activated silicas were then removed by filtration and thoroughly rinsed with distilled water ( 250 $\mathrm{mL}$ ). Enzyme solution ( $5 \mathrm{~mL}, 80 \mathrm{mg}$ of Proleather per $\mathrm{mL}$ ) in $0.1 \mathrm{M}$ phosphate buffer $\mathrm{pH} 8.0$ was added to 20 $\mathrm{mL}$ of the same buffer with the activated support. Then, $936 \mu \mathrm{L}$ of an aqueous solution of sodium cyanoborohydride, $0.08 \%(\mathrm{w} / \mathrm{v})$ in $0.1 \mathrm{M}$ phosphate buffer $\mathrm{pH}$ 8.0, was added $1 \mathrm{~h}$ after addition of enzyme solution addition. The coupling reaction was performed for $7 \mathrm{~h}$ at $25^{\circ} \mathrm{C}$ with orbital shaking $(90 \mathrm{rpm})$, after which time the solids were filtered and rinsed with $0.1 \mathrm{M}$ Tris- $\mathrm{HCl}$ buffer $\mathrm{pH}$ 8.5. Finally, the immobilized enzyme was dried in a vacuum in the presence of phosphorus pentoxide, for $24 \mathrm{~h}$, before use.

Immobilization on $\mathbf{S}_{\mathbf{x}} \mathbf{S}_{\text {TESPM-pHEMA }}$ Supports. CDI was used as the activating agent for coupling Proleather to the hydroxyl groups of HEMA grafted into silica. Two immobilization protocols were used regarding the application of the immobilized enzyme in aqueous solution (protocol A) or organic medium (protocol B). In protocol A, $50 \mathrm{mg}$ of SXSTESPM-pHEMA silica was added to $5.0 \mathrm{~mL}$ of anhydrous DMSO containing $150 \mathrm{mg}$ of CDI. The activation reaction was carried out at $25^{\circ} \mathrm{C}$ without stirring for $2 \mathrm{~h}$. The activated silica was then removed by filtration and washed with water $(3 \times 10 \mathrm{~mL})$. The coupling reactions were performed in the same way as described for the $S_{x} S_{\text {APTES }}$ supports (protocol A), for $18 \mathrm{~h}$ at $25^{\circ} \mathrm{C}$, but in the absence of sodium cyanoborohydride.

In protocol $B, 600 \mathrm{mg}$ of $\mathrm{S}_{\mathrm{X}} \mathrm{S}_{\text {TESPM-PHEMA }}$ silica was added to $40 \mathrm{~mL}$ of anhydrous DMSO containing $1.2 \mathrm{~g}$ of CDI. The activation reaction was carried out at $25^{\circ} \mathrm{C}$ with orbital shaking $(90 \mathrm{rpm})$ for $2 \mathrm{~h}$. The activated silica was then removed by filtration and washed with water $(100 \mathrm{~mL})$. The coupling reactions were performed in the same way as described for the $S_{x} S_{\text {APTES }}$ supports (protocol B), for $8 \mathrm{~h}$ at $25^{\circ} \mathrm{C}$. Finally, the immobilized enzyme was dried in a vacuum in the presence of phosphorus pentoxide for $24 \mathrm{~h}$ before use.

Proteolytic Activity Assay. The proteolytic assay was performed either in the presence of $0.1 \mathrm{~mL}$ of enzyme solution containing a given amount of enzyme or $\sim 50 \mathrm{mg}$ of immobilized enzyme (see above), in the case of soluble and immobilized enzyme, respectively. Enzymes were added to the reaction media formed by a mixture of 1 $\mathrm{mL}$ of $0.1 \mathrm{M}$ phosphate buffer $\mathrm{pH} 8.0$ with $5 \mathrm{~mL}$ of $1.0 \%$ $(\mathrm{w} / \mathrm{v})$ casein solution. The mixture was incubated for a desired time at $37^{\circ} \mathrm{C}$ with magnetic stirring (200 rpm), and a $0.5-\mathrm{mL}$ aliquot was taken and added to an equal vol ume of $0.4 \mathrm{M}$ trichloroacetic acid (for the immobilized enzymes a preceding centrifugation step at $5000 \mathrm{rpm}$ for 1 min was necessary). The resulting precipitate was removed by centrifugation (5000 rpm, 2 min) after standing for $25 \mathrm{~min}$ at $25^{\circ} \mathrm{C}$. The supernatant $(0.5 \mathrm{~mL})$ was placed in a test tube containing $5 \mathrm{~mL}$ of $0.4 \mathrm{M}$ sodium carbonate and $0.5 \mathrm{~mL}$ of 5 -fold diluted Folin's reagent. After thorough mixing, the solution was allowed to stand for $20 \mathrm{~min}$ at $37^{\circ} \mathrm{C}$, and the absorbance was measured spectrophotometrically at $660 \mathrm{~nm}$. The absorbance values were then converted to equivalent tyrosine concentrations using a tyrosine calibration curve. One unit of protease activity $(U)$ is defined as the quantity of enzyme needed to produce the amino acid equivalent of $1 \mu \mathrm{g}$ of tyrosine per min. In parallel with the enzyme assays, blank reactions without enzyme (with or without modified silicas) were performed.

Protein Determination and Active Sites Titration. The protein content in the crude or immobilized enzyme preparations was determined by the Sedmak method
(15), using bovine serum al bumin (BSA) as the standard (the protein is, therefore, expressed in BSA equivalents). The amount of protein bonded onto silica supports was determined indirectly from the difference between the initial total protein exposed to the supports and the amount of protein recovered in the wash.

The soluble and immobilized enzymes were titrated in aqueous solution prior to use to determine the fraction of active centers present in a given sample. These titrations were performed according to the method of Schonbaum (16) via the spectrophotometric determination (at $335 \mathrm{~nm}$ ) of enzyme acylation by $\mathrm{N}$-trans-cinnamoylimidazole $(\mathrm{TCl})$. In case of the immobilized enzyme the original protocol was adapted. In this case, $\mathrm{TCl}$ ( $70 \mu \mathrm{L}, 2.05 \mathrm{mg} / \mathrm{mL}$ acetonitrile) was added to a suspension of the biocatalyst $(500 \mathrm{mg}$, using immobilization protocol B) in $0.1 \mathrm{M}$ acetate buffer pH $5.0(6 \mathrm{~mL})$ and mixed for $1 \mathrm{~min}$. Afterward, the suspension was filtered using a syringe coupled with a filter (Millipore, Millex HV $13 \mathrm{~mm}$ ) and placed in a cuvette. The spectrophotometric determination at $335 \mathrm{~nm}$ was done 2.7 min after the initial addition of $\mathrm{TCl}$. In parallel, a calibration curve was performed. The TCl solutions were added to $6 \mathrm{~mL}$ of $0.1 \mathrm{M}$ acetate buffer $\mathrm{pH} 5.0$ and mixed for $1 \mathrm{~min}$, and $1 \mathrm{~mL}$ was taken for spectrophometric reading at $335 \mathrm{~nm}$ (2.7 min after the initial addition of $\mathrm{TCl}$; this takes into account the slow decrease in absorbance due to the spontaneous hydrolysis of the titrant) (16).

Enzymatic Transesterification Reaction of Sucrose with DVA. The enzymes were "pH-adjusted" (with the exception of porcine pancreatic lipase type II and lipase B from Candida antarctica) in the presence of 20 mM phosphate buffer at pH 8.0 (Proleather FG-F, Protease S, and subtilisin Carlsberg) or at pH 7.5 (Proteases A, N, P; Lipases A, AY, M, PS). After flash-freezing in liquid nitrogen, the samples were lyophilized on a Labconco freeze-drier (Labconco Corp., Kansas City, MO) for $48 \mathrm{~h}$. Enzymes were screened for their ability to catalyze sucrose ester synthesis by adding $75 \mathrm{mg}$ of enzyme powder (except for freeze-dried subtilisin Carlsberg and lipase B from Candida antarctica, which were employed at 50 and $125 \mathrm{mg}$, respectively) to $4.8 \mathrm{~mL}$ of DMF or pyridine containing $0.1 \mathrm{M}$ sucrose. The reaction was initiated by adding $190 \mu \mathrm{L}$ of DVA $(0.2 \mathrm{M})$, and the mixture was shaken at $250 \mathrm{rpm}\left(45^{\circ} \mathrm{C}\right)$ in a temperaturecontrolled New Brunswick Scientific C24 orbital shaker (E dison, NJ ). Periodically, 100- $\mu \mathrm{L}$ aliquots were removed, centrifuged at $4000 \mathrm{rpm}$ for $5 \mathrm{~min}$, and analyzed by GC. The extent of the reaction was calculated from the decrease in the concentration of the sugar substrate.

The transesterification reactions of different sugars with DVA using free Proleather were performed in 4.8 $\mathrm{mL}$ of DMF or pyridine containing $0.1 \mathrm{M}$ sugar and 15 or $75 \mathrm{mg}$ of "pH-adjusted" Proleather, respectively. For immobilized Proleather, the reactions were performed with $200 \mathrm{mg}$ of biocatalyst. The reactions were initiated by adding $190 \mu \mathrm{L}$ of DVA (0.2 M), and the mixtures were shaken at $250 \mathrm{rpm}\left(45^{\circ} \mathrm{C}\right)$. Periodically, aliquots were removed and analyzed by GC (see above).

Preparative-scale synthesis of sucrose ester was performed in $150 \mathrm{~mL}$ of DMF containing $0.1 \mathrm{M}$ sucrose and $0.2 \mathrm{M}$ DVA with $3 \mathrm{mg} / \mathrm{mL}$ Proleather at $45^{\circ} \mathrm{C}$ for $27 \mathrm{~h}$. The reaction was terminated by filtering off the enzyme, and the solvent was subsequently removed by rotary evaporation. The oily residue was purified by silica gel flash chromatography $(7.6 \times 20 \mathrm{~cm})$ with a solvent mixture of ethyl acetate/methanol/water (24:1:0.5, v/v). Two fractions were collected, and the solvent was evaporated. Then, the products isolated were dissolved in water 
Table 2. Chemical Shifts (ppm) of Sucrose and Sucrose 2-O-Vinyladipate $\left(\mathrm{D}_{2} \mathrm{O}\right)$

\begin{tabular}{lrcc}
\hline carbon & sucrose & 2-monoester & $\Delta \delta$ \\
\hline 1 & 93.47 & 91.00 & -2.47 \\
2 & 72.37 & 74.00 & +1.63 \\
3 & 73.88 & 71.74 & -2.14 \\
4 & 70.54 & 70.71 & +0.17 \\
5 & 73.71 & 73.77 & +0.06 \\
6 & 61.44 & 61.60 & +0.16 \\
$1^{\prime}$ & 62.69 & 62.48 & -0.21 \\
$2^{\prime}$ & 105.02 & 105.36 & +0.34 \\
$3^{\prime}$ & 77.77 & 76.99 & -0.78 \\
$4^{\prime}$ & 75.32 & 75.25 & -0.07 \\
$5^{\prime}$ & 82.67 & 82.89 & +0.22 \\
$6^{\prime}$ & 63.65 & 63.77 & +0.12 \\
adipate & & $176.57,174.68,34.73$, & \\
& & $34.52,24.84,24.79$ & \\
vinyl & & $142.55,100.63$ &
\end{tabular}

and freeze-dried for $48 \mathrm{~h}$. The fast moving product $\left(\mathrm{R}_{\mathrm{f}}=\right.$ 0.89 ), a minor component (isolated yield $<3 \%$ ), was a diester (as determined by ${ }^{1} \mathrm{H}$ NMR) and was not further investigated. The major product $\left(R_{f}=0.55\right)$ was a monoester, sucrose 2-O-vinyladipate (1.72 g, 22.4\%): ${ }^{1} \mathrm{H}$ $\operatorname{NMR}\left(\mathrm{D}_{2} \mathrm{O}\right) \delta 7.22\left(\mathrm{dd}, 1 \mathrm{H},{ }^{3} \mathrm{~J} \times \mathrm{b}\right.$ (trans) $=13.9 \mathrm{~Hz},{ }^{3} \mathrm{xa(cis)}=$ $6.3 \mathrm{~Hz}$, vinyl), $5.55(\mathrm{~d}, 1 \mathrm{H}, \mathrm{J}=3.7 \mathrm{~Hz}, \mathrm{H} 1), 5.01(\mathrm{dd}, 1 \mathrm{H}$, ${ }^{2} \mathrm{~J}_{\mathrm{ba}}=1.5 \mathrm{~Hz},{ }^{3} \mathrm{bx}$ (trans) $=14.0 \mathrm{~Hz}$, vinyl), 4.76 (dd, $1 \mathrm{H}$, ${ }^{2} \mathrm{~J}_{\mathrm{ab}}=1.8 \mathrm{~Hz},{ }^{3} \mathrm{~J}_{\mathrm{ax}(\mathrm{cis})}=6.1 \mathrm{~Hz}$, vinyl), $4.70(\mathrm{dd}, 1 \mathrm{H}, \mathrm{H} 2$, under the water peak), $4.24\left(\mathrm{~d}, 1 \mathrm{H}, \mathrm{J}=8.9 \mathrm{~Hz}, \mathrm{H}^{\prime}\right), 4.06$ $\left(\mathrm{t}, 1 \mathrm{H}, \mathrm{J}=8.6 \mathrm{~Hz}, \mathrm{H}^{\prime}\right), 3.97(\mathrm{t}, 1 \mathrm{H}, \mathrm{J}=9.8 \mathrm{~Hz}, \mathrm{H} 3$ ), $3.89\left(\mathrm{~m}, 2 \mathrm{H}, \mathrm{H} 5\right.$ and $\left.\mathrm{H}^{\prime}\right), 3.83\left(\mathrm{~m}, 4 \mathrm{H}, \mathrm{H} 6\right.$ and $\left.\mathrm{H}^{\prime}\right), 3.60$ ( $m, 2 \mathrm{H}, \mathrm{H} 4$ and $\left.\mathrm{Hl}^{\prime} \mathrm{a}\right), 3.51$ (d, $\left.\mathrm{H}_{\mathrm{H}} \mathrm{J}=12.2 \mathrm{~Hz}, \mathrm{H} \mathrm{l}^{\prime} \mathrm{b}\right)$, 2.54 (s, $4 \mathrm{H}, \alpha \mathrm{CH}_{2}$, adypate), 1.71 (s, $4 \mathrm{H}, \beta \mathrm{CH}_{2}$, adypate). For ${ }^{13} \mathrm{C}$ NMR $\left(\mathrm{D}_{2} \mathrm{O}\right)$ data, see Table 2 .

Enzyme Reuse After each cycle, the reaction mixture was centrifuged (4000 rpm, $5 \mathrm{~min}$ ) and an aliquot (100 $\mu \mathrm{L}$ ) from the supernatant was taken for GC analyses (see above). Afterward, the supernatant was decanted, and the free (insoluble in DMF) or immobilized enzyme washed with $5 \mathrm{~mL}$ of DMF. The suspension was then centrifuged, the supernatant was decanted, and the free or immobilized enzyme was subjected to the next transesterification reaction.

\section{Results and Discussion}

Enzyme Screening for Sugar Acylation. Enzymatic synthesis of sugar vinyl esters is limited by the poor solubility of sugars in all but a few, very hydrophilic organic solvents such as pyridine and dimethylformamide, with the latter being a stronger solvent. For example, the solubility of sucrose in DMF at $30^{\circ} \mathrm{C}$ is ca. 5 times greater than in pyridine (17). We screened a number of lipases and proteases in both pyridine and DMF for the transesterification of sucrose with DVA (45 $\left.{ }^{\circ} \mathrm{C}\right)($ Table 1$)$. The best enzymes in pyridine were Proleather and subtilisin Carlsberg, whereas in DMF a broad range of enzymes showed high activity, with Proleather being extremely active. Based on the high reactivity of Proleather, we selected this enzyme for further study.

The regioselectivity of enzymes is a key criterion for their use in synthetic transformations and was of practical concern to us in this study. To that end, larger-scale reactions were performed with Proleather at $45^{\circ} \mathrm{C}$ using $0.1 \mathrm{M}$ sucrose and $0.2 \mathrm{M}$ DVA in DMF for $27 \mathrm{~h}$. Sucrose esters were purified by flash silica gel chromatography, and a combination of unidimensional $\left({ }^{1} \mathrm{H}\right.$ and $\left.{ }^{13} \mathrm{C}\right)$ and bidimensional $\left({ }^{1} \mathrm{H}-{ }^{1} \mathrm{H}\right.$ COSY and ${ }^{1} \mathrm{H}-{ }^{13} \mathrm{C}$ HMQC) NMR analysis (see Supporting Information) was undertaken to determine the acylation sites. Following the Yoshimoto strategy (18), the chemical shift of acylated carbon should
Scheme 1. Enzymatic Synthesis of Sucrose 2-0-Vinyladipate by Proleather in DMF

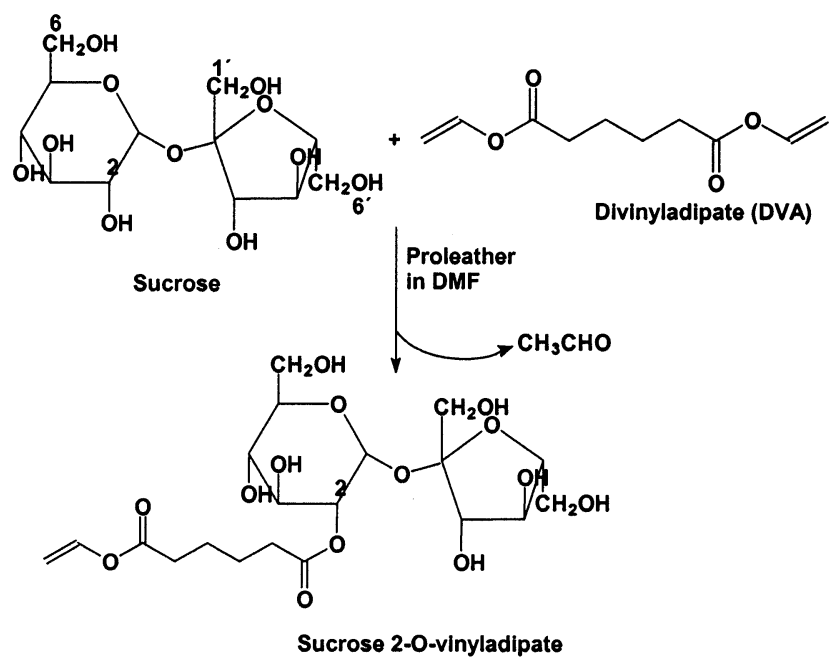

result in a downfield shift and the adjacent carbon should result in a concomitant upfield shift. The chemical shifts of the other carbon atoms are hardly affected. According to the carbon chemical shifts depicted in Table 2, the major product (isolated yield of $22.4 \%$ ) was sucrose 2-Ovinyladipate, a monoester (Scheme 1).

Surprisingly, Proleather enzyme is able to acylate sucrose preferentially at the secondary 2-hydroxyl group in the glucopyranose residue as opposed to the less sterically hindered primary hydroxyl groups of the sucrose molecule. This regi osel ective performance is quite distinct from the one exhibited by other enzymes in sugar acylation described in the literature. For example, several proteases from the subtilisin family acylate sucrose preferentially at the $1^{\prime}-\mathrm{OH}(7,17,19-21)$ with shortchain ester donors, whereas lipases from Mucor michei (22), Candida antarctica (23), and Humi cola lanuginosa (11) acylate sucrose preferentially at the $6-\mathrm{OH}$ in the glucose ring, yielding a mixture of 6- and 6 '-monoesters. Furthermore, it has been shown that Proleather FG-F $(15 \mathrm{mg} / \mathrm{mL}$ ) catalyzed the acylation of sucrose with vinyl acrylate (pyridine, 5 days, $45^{\circ} \mathrm{C}$ ) yielding sucrose $1^{\prime}-\mathrm{O}$ acrylate as the main product (isolated yield of $28 \%$ ) (7). These results highlight the wide diversity of regioselectivity among related enzymes used under different solvent conditions and with different substrates. Furthermore, the ability of Proleather to catalyze the regioselective acylation of sucrose at a secondary hydroxyl group without prior protection of the primary hydroxyl groups is intriguing and has not been demonstrated previously (24). This finding may lead to synthetic schemes that result in the direct protection and/or reaction of secondary hydroxyl groups in other sugars and sugar-containing compounds (e.g., nucleosides, natural products, etc.)

The activity and sel ectivity of Proleather was not due to an underlying contaminating protein in the commercial preparation. SDS-PAGE showed only one significant band for the Proleather crude preparation (data not shown). Moreover, active site titration of the crude enzyme preparation with $\mathrm{TCl}$ showed that ca. $4.1 \%$ of the total preparation mass was active enzyme (a similar value was obtained by total protein measurement); the balance presumably was composed of nonproteinaceous stabilizers.

Screening of Silica Supports for Enzyme Immobilization. Encouraged by the reactivity and unique 
Table 3. Physical and Chemical Properties of the Silica Derivatives

\begin{tabular}{|c|c|c|c|c|c|c|c|}
\hline sample & $\begin{array}{l}\text { particle size } \\
(\mu \mathrm{m})^{\mathrm{a}}\end{array}$ & $\begin{array}{l}\text { surface area } \\
\left(\mathrm{m}^{2} \mathrm{~g}^{-1}\right)^{\mathrm{b}}\end{array}$ & $\begin{array}{c}\text { mean pore } \\
\text { diameter }(\AA)^{c}\end{array}$ & $\begin{array}{l}\text { true density } \\
\qquad\left(g L^{-1}\right)^{d}\end{array}$ & $\begin{array}{c}\text { porosity } \\
\text { (\%)e }^{\mathrm{e}}\end{array}$ & $\begin{array}{c}\text { yield of } \\
\text { grafting (\%) }\end{array}$ & $\begin{array}{l}\text { water vapor } \\
\text { sorption (\%) }\end{array}$ \\
\hline $\mathrm{S}_{300} \mathrm{~S}_{\text {TESPM-pHEMA }}$ & 30 & 46 & $130 / 550$ & 2.14 & 75.9 & $2.3 / 12.9$ & 15.6 \\
\hline $\mathrm{S}_{300} \mathrm{~S}_{\text {APTES }}$ & 30 & 58 & $130 / 550$ & 2.27 & 81.1 & $1.5 /-$ & 21.9 \\
\hline $\mathrm{S}_{1000} \mathrm{~S}_{\text {TESPM-pHEMA }}$ & 29 & 35 & $130 / 1200$ & 2.23 & 79.6 & $0.4 / 6.3$ & 6.5 \\
\hline $\mathrm{S}_{1000} \mathrm{~S}_{\text {APTES }}$ & 29 & 40 & $130 / 1200$ & 2.34 & 83.1 & $1.2 /-$ & 6.9 \\
\hline
\end{tabular}

${ }^{a}$ Determined by laser diffraction ( $d_{50}$ results). ${ }^{b}$ E valuated by BET (gas adsorption analysis). ${ }^{c}$ Mode of first peak/mode of second peak, determined by mercury porosimetry. ${ }^{d}$ Determined by helium pycnometry. ${ }^{e}$ Calculated as [(true density - bulk density)/true density] $\times$ 100. ${ }^{f}$ The first value is related to the yield of silanization process and the second value to the yield of the HEMA grafting. The values in each case were calculated from TGA assays. The ratio $S_{x} S_{A P T E S} / S_{x}$ (for $S_{300} S_{A P T E S}$ and $S_{1000} S_{A P T E S}$ ) or $S_{x} S_{T E S P M-p H E M A} / S_{x} S_{T E S P M}$ taking in account $S_{x} S_{T E S P M} / S_{x}$ (for $S_{300} S_{T E S P M-p H E M A}$ and $S_{1000} S_{\text {TESPM-pHEMA }}$ ) were calculated. $9 \%$ sorption $=\left[\left(M_{w}-M_{d}\right) / M_{d}\right] \times 100$, where $M_{w}$ is the wet mass and $\mathrm{M}_{\mathrm{d}}$ the dry mass.

Table 4. Influence of Different Silica Derivatives on Proleather Proteolytic Activitya

\begin{tabular}{|c|c|c|c|c|c|}
\hline support & $\begin{array}{c}\text { immobilized protein } \\
\text { (mg of prot per g of silica) }\end{array}$ & $\begin{array}{c}\text { percentage of } \\
\text { immobilized protein (\%) }\end{array}$ & $\begin{array}{c}\text { activity } \\
(\text { U/g silica })^{d}\end{array}$ & $\begin{array}{l}\text { specific activity } \\
\text { (U/mg of protein) }\end{array}$ & $\begin{array}{c}\text { relative } \\
\text { activity (\%)e }\end{array}$ \\
\hline 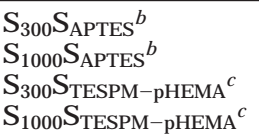 & $\begin{array}{l}0.45 \pm 0.06 \\
0.17 \pm 0.04 \\
1.3 \pm 0.1 \\
1.4 \pm 0.1\end{array}$ & $\begin{array}{r}17.3 \pm 2.4 \\
6.7 \pm 1.4 \\
51.5 \pm 4.2 \\
55.6 \pm 2.8\end{array}$ & $\begin{array}{r}13.3 \pm 1.2 \\
10.4 \pm 1.7 \\
8.1 \pm 0.6 \\
9.1 \pm 0.2\end{array}$ & $\begin{array}{r}29.7 \pm 2.8 \\
59.9 \pm 9.6 \\
6.0 \pm 0.4 \\
6.3 \pm 0.1\end{array}$ & $\begin{array}{r}26.3 \\
53.1 \\
5.3 \\
5.6\end{array}$ \\
\hline
\end{tabular}

a The values reflect the mean and standard deviation of three different measurements. ${ }^{b}$ Silicas silanized with 3-aminopropyltriethoxysilane containing $\mathrm{NH}_{2}$-terminal groups. The enzymes were immobilized on these supports via glutaral dehyde coupling. ${ }^{c}$ Silicas silanized with 3-(trimethoxysilyl) propyl methacrylate and then grafted with hydroxyethyl methacrylate (containing $\mathrm{OH}$-terminal groups). The enzymes were immobilized on these supports via CDI coupling. ${ }^{d}$ The activity was determined by sampling 60 min after the contact of the substrate with the immobilized enzyme was made. e The relative activity was calculated from the ratio (specific activity for immobilized enzyme/specific activity for soluble enzyme) $\times 100$. The specific activity of soluble enzyme was $112.9 \pm 2.0 \mathrm{U} / \mathrm{mg}$.

regioselectivity of Proleather in DMF, we proceeded to immobilize the enzyme onto silica supports. Two sets of chemically distinct silica supports were used. In one set, the original silicas were silanized with $\mathrm{S}_{\mathrm{APTES}}$, providing terminal $\mathrm{NH}_{2}$ groups (denoted as $\mathrm{S}_{x} \mathrm{~S}_{\text {APTES }}$ silicas). U pon treatment with glutaraldehyde, the enzyme (via the $\epsilon$-amino group of lysine residues) was immobilized to these supports. In a second set, the silicas were silanized with STESPM and then grafted with HEMA using X-ray irradiation (denoted as $\mathrm{S}_{\mathrm{X}} \mathrm{S}_{\text {TESPM-pHEMA }}$ silicas). Following treatment with CDI, the enzyme (also via the $\epsilon$-amino group of Iysine residues) was immobilized onto these supports. The silicas were physically characterized (Table 3).

The proteolytic activity results of immobilized Proleather into different silica supports are shown in Table 4. In $\mathrm{S}_{300} \mathrm{~S}_{\text {APTES}}$-Silica supports, with a bimodal distribution of pore sizes, $130 / 550 \AA$, and a surface area higher than that of $\mathrm{S}_{1000} \mathrm{~S}_{\text {APTES}}$-Silica supports (Table 3), the yield of protein immobilized is higher than in $\mathrm{S}_{1000} \mathrm{~S}_{\text {APTES}}$-Silica supports. However, the specific activity of the enzyme on $\mathrm{S}_{1000} \mathrm{~S}_{\text {APTES }}$ is about twice that on $\mathrm{S}_{300} \mathrm{~S}_{\text {APTES}}$. This may be due to the greater likelihood of multipoint attachment of enzyme in the $S_{300} S_{\text {APTES }}$ supports as opposed to the $\mathrm{S}_{1000} \mathrm{~S}_{\text {APTES }}$ supports, which have fewer glutaraldehyde groups. This then may result in lower activity of the $\mathrm{S}_{300} \mathrm{~S}_{\text {APTES }}$ and to the likely reduced protein mobility of the protein attached through multiple sites.

I mmobilization of the enzyme onto grafted silicas with HEMA $\left(S_{300} S_{\text {TESPM-pHEMA }}\right.$ and $\left.S_{1000} S_{\text {TESPM-PHEMA }}\right)$ resulted in an increase in the immobilization yield (ranging from ca. 3- to 7-fold) yet a reduction in the enzyme activity as compared to the $S_{x} S_{\text {APTES }}$ silicas. The increase in the immobilization yield is mainly due to the existence of a large content of $\mathrm{p}(\mathrm{HEMA}$ ) hydroxyl groups for enzyme immobilization (see yield of grafting in Table 3). The reduction of enzyme activity in the $\mathrm{S}_{x} \mathrm{~S}_{\text {TESPM-pHEMA }}$ silicas is likely due to the low accessibility of the Proleather entangled in the pHEMA matrix to the large casein substrate. It may also be possible that the $\mathrm{S}_{x} \mathrm{~S}_{\text {TESPM-PHEMA }}$ silicas are influenced by the intraparticle diffusional limitations of the substrate. However, the observable modulus $(\Phi)$ (25) for immobilized Proleather into the different silicas was less than 0.01 (26), which corresponds to an internal effectiveness factor $\left(\eta_{1}\right.$, which is the ratio between the actual observed activity and the activity that would be obtained in the absence of intraparticle diffusion limitations) of ca. 1. Thus intraparticle mass transfer limitations were unlikely. Indeed, this is not surprising given the low particle size of the different silicas and the slow enzyme activity in the proteolysis of casein.

Finally, the relative activity of immobilized Proleather into $S_{X} S_{\text {TESPM - pHEMA }}$ and $\mathrm{S}_{X} \mathrm{~S}_{\text {APTES }}$ silicas ranged from $5 \%$ to $26 / 53 \%$, respectively, and is similar to activities observed with other enzymes incorporated into silica supports (27).

Synthetic Activity of I mmobilized Proleather. For synthetic purposes, the enzyme immobilization protocol used for aqueous reaction was scaled up to yield higher amounts of immobilized enzyme. Furthermore, larger amounts of biocatalyst enabled accurate active site titration to be performed, a critical requirement for calculating the specific activity of the enzyme.

The high intrinsic activity of the immobilized Proleather onto the silica supports encouraged us to use this preparation in the acylation of sucrose in DMF and pyridine. The highest synthetic activity was obtained when $\mathrm{S}_{x} \mathrm{~S}_{\text {TESPM }}$-pHEMA Supports were used in DMF (Figure 2 , Table 5), with $100 \%$ conversion in $24 \mathrm{~h}$. Furthermore, from GC analysis it appears that the regioselectivity of immobilized Proleather was similar to that of free Proleather, as the most representative peak in the chromatograms had the same retention time.

Comparison of the proteolytic (Table 4) and synthetic (Table 5) activities of the protease into different supports shows that the trend observed in the specific enzyme activity in aqueous medium does not differ significantly from the one in organic solvent. In both cases, Proleather immobilized into $S_{x} S_{A P T E S}$ supports exhibited higher specific activity than that of S $S_{\text {TESPM-pHEMA }}$ ones. Nevertheless, higher total synthetic activity of Proleather immobilized into $S_{x} S_{\text {TESPM-pHEMA }}$ over $\mathrm{S}_{x} \mathrm{~S}_{\text {APTES }}$ supports was observed, which differs from the proteolytic results 
Table 5. Influence of Support in Synthetic Activitya of Immobilized Proleather in Either DMF or Pyridine

\begin{tabular}{|c|c|c|c|c|c|c|}
\hline \multirow[b]{2}{*}{ biocatalyst } & \multicolumn{3}{|c|}{ DMF } & \multicolumn{3}{|c|}{ pyridine } \\
\hline & $\begin{array}{c}\text { activity } \\
\text { (mmol/min·g } \\
\text { silica) }\end{array}$ & $\begin{array}{l}\text { specific activity } \\
(\mu \mathrm{mol} / \mathrm{min} \cdot \mathrm{mg} \\
\text { active enzyme) }\end{array}$ & $\begin{array}{c}\text { enhance- } \\
\text { ment }^{b}\end{array}$ & $\begin{array}{c}\text { activity } \\
\text { (mmol/min·g } \\
\text { silica) }\end{array}$ & $\begin{array}{c}\text { specific activity } \\
(\mu \mathrm{mol} / \mathrm{min} \cdot \mathrm{mg} \\
\text { active enzyme) }\end{array}$ & $\begin{array}{c}\text { enhance- } \\
\text { ment }^{\mathrm{b}}\end{array}$ \\
\hline free Proleather & & 3.24 & & & 0.0320 & \\
\hline $\mathrm{S}_{300} \mathrm{~S}_{\text {APTES }}$-Proleather & 22.1 & 3.18 & c & 0.265 & 0.0382 & 1.2 \\
\hline $\mathrm{S}_{1000} \mathrm{~S}_{\text {APTES}}$-Proleather & 46.9 & 31.3 & 9.7 & 0.298 & 0.199 & 6.2 \\
\hline $\mathrm{S}_{300} \mathrm{~S}_{\text {TESPM}-\mathrm{pHEMA}}-\mathrm{Proleather}$ & 30.7 & 2.45 & c & 0.372 & 0.0298 & c \\
\hline $\mathrm{S}_{1000} \mathrm{~S}_{\text {TESPM-pHEMA-Proleather }}$ & 81.6 & 6.26 & 1.9 & 0.649 & 0.0498 & 1.6 \\
\hline
\end{tabular}

a The synthetic activity was assessed in the transesterification reaction of sucrose with DVA. Each value represents the mean of two separate determination. ${ }^{b}$ Enhancement, calculated as the ratio of the immobilized and nonimmobilized specific activities. ${ }^{c}$ No enhancement.

Table 6. Influence of Different Sugars in Transesterification Activity of Immobilized Proleather in DMF

\begin{tabular}{|c|c|c|c|c|}
\hline biocatalyst & sugar & $\begin{array}{c}\text { activity } \\
(\mu \mathrm{mol} / \mathrm{min} \cdot \mathrm{g} \text { silica })\end{array}$ & $\begin{array}{c}\text { specific activity } \\
(\mu \mathrm{mol} / \mathrm{min} \cdot \mathrm{mg} \text { active enzyme })\end{array}$ & enhance menta \\
\hline free Proleather & $\begin{array}{l}\alpha \text {-methyl glucose } \\
\text { trehalose } \\
\text { maltose }\end{array}$ & & $\begin{array}{l}0.485 \\
0.634 \\
1.18\end{array}$ & \\
\hline $\mathrm{S}_{300} \mathrm{~S}_{\text {APTES }}$-Proleather & $\begin{array}{l}\alpha \text {-methyl glucose } \\
\text { trehalose } \\
\text { maltose }\end{array}$ & $\begin{array}{l}0.0611 \\
8.16 \\
30.04\end{array}$ & $\begin{array}{l}0.00880 \\
1.17 \\
4.32\end{array}$ & $\begin{array}{l}\mathrm{b} \\
1.8 \\
3.7\end{array}$ \\
\hline
\end{tabular}

a Enhancement, calculated as the ratio of the immobilized and nonimmobilized specific activities. ${ }^{b}$ No enhancement.

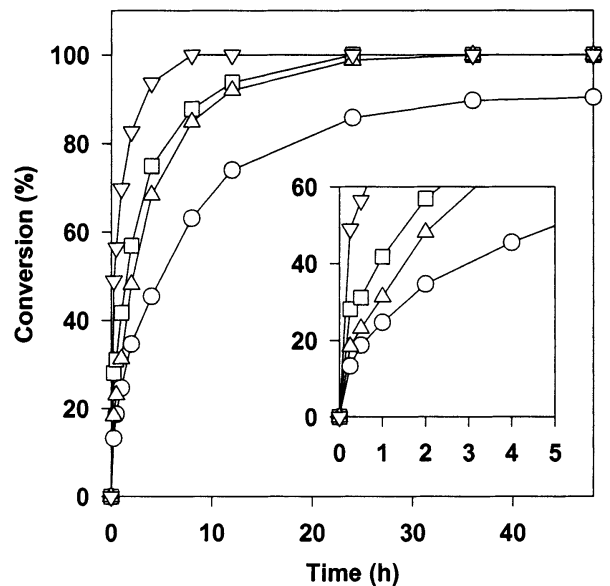

Figure 1. Time course of transesterification reaction of sucrose and DVA catalyzed by Proleather immobilized onto $S_{300} S_{\text {APTES }}$ $(O), \mathrm{S}_{1000} \mathrm{~S}_{\text {APTES }}(\square), \mathrm{S}_{300} \mathrm{~S}_{\text {TESPM }}$-pHEMA $(\triangle)$, and $\mathrm{S}_{1000} \mathrm{~S}_{\text {TESPM }}$-pHEMA $(\nabla)$ supports, in DMF. Each value represents the mean of two separate determination.

obtained previously. This is ascribed to the high content of enzyme loaded into $S_{X} S_{\text {TESPM-PHEMA }}$ supports and the reduction of spatial restriction effects by the use of lower molecular weight substrates (as compared to casein in the proteolysis reaction).

Clearly, the mean pore size of the silica supports plays a major role in the enzyme catalytic performance; the synthetic specific activity of the $S_{1000} S_{y^{-}}$(but not $S_{300} S_{y^{-}}$) immobilized Proleather was higher than that of the free enzyme. The difference in sucrose acylation activity between the two silica supports is not a result of diffusional limitations, as we have showed above that substrate diffusion is not rate-limiting in these systems. Thus, the synthetic activity enhancement of $S_{1000} S_{y}$ over $\mathrm{S}_{300} \mathrm{~S}_{\mathrm{y}}$ may be due to the intrinsic difference in the state of the enzyme attached to the silica pore walls and to the greater enzyme mobility in $\mathrm{S}_{1000} \mathrm{~S}_{\mathrm{y}}$ silicas (see above). Furthermore, the synthetic activity enhancement of Proleather immobilized into $\mathrm{S}_{1000} \mathrm{~S}_{\text {APTES }}$ and $\mathrm{S}_{1000} \mathrm{~S}_{\text {TESPM-pHEMA }}$ supports (ca. 10- and 2-fold, respectively) as compared to the free counterpart may be ascribed to an increase of enzyme dispersion that exposes the enzyme more efficiently to the substrate $(10,11)$.

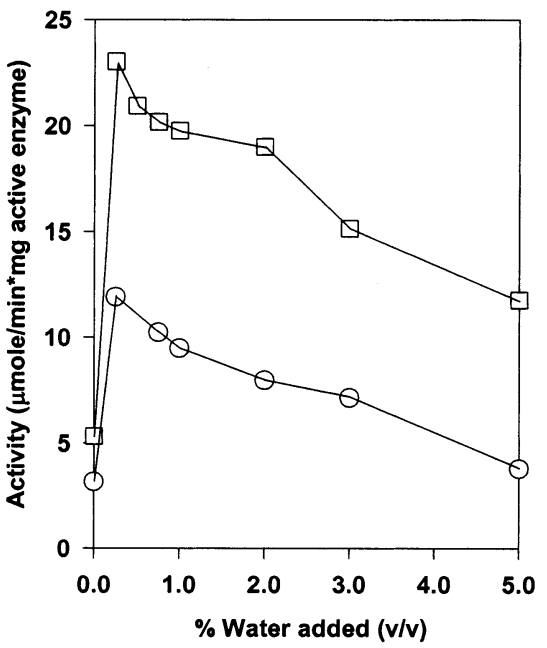

Figure 2. Transesterification activity of native $(\square)$ and immobilized (O) Proleather into $\mathrm{S}_{300} \mathrm{~S}_{\text {APTES }}$, at different water additions. The amount of active enzyme in the native and in the immobilized form used in the transesterification reaction was 0.434 and $1.39 \mathrm{mg}$, respectively. The water content on native and $\mathrm{S}_{300} \mathrm{~S}_{\text {APTES }}$-immobilized Proleather before reaction was $5.6 \%$ and $1.7 \%$, respectively.

Encouraged by the enhanced performance of immobilized Proleather, we extended the acylation reaction to other sugars using $\mathrm{S}_{300} \mathrm{~S}_{\text {APTES }}$-immobilized Proleather as biocatalyst $\left(\mathrm{S}_{300} \mathrm{~S}_{\text {APTES }}\right.$ instead $\mathrm{S}_{1000} \mathrm{~S}_{\text {APTES }}$ was used for enzyme immobilization because of the greater availability of the former). The reactivity of the immobilized Proleather was 1.8- and 3.7-fold higher than the free enzyme with trehalose and maltose, respectively (Table 6). Interestingly, the opposite was observed for $\alpha$-methylglucoside. Therefore, for the same biocatalyst preparation, the benefits of immobilization may differ.

Effect of Water on Sucrose Acylation Activity in DMF. It is well-established that enzyme structure and function is strongly dependent on the water content of the reaction mixture (28). To that end, the role of the water in the Proleather-catalyzed acylation of sucrose with DVA was investigated with both the $\mathrm{S}_{300} \mathrm{~S}_{\text {APTES- }}$ supported enzyme and the free enzyme at several water contents. In both cases an optimal water content was found. Specifically, the addition of $0.25 \%(\mathrm{v} / \mathrm{v})$ water to 


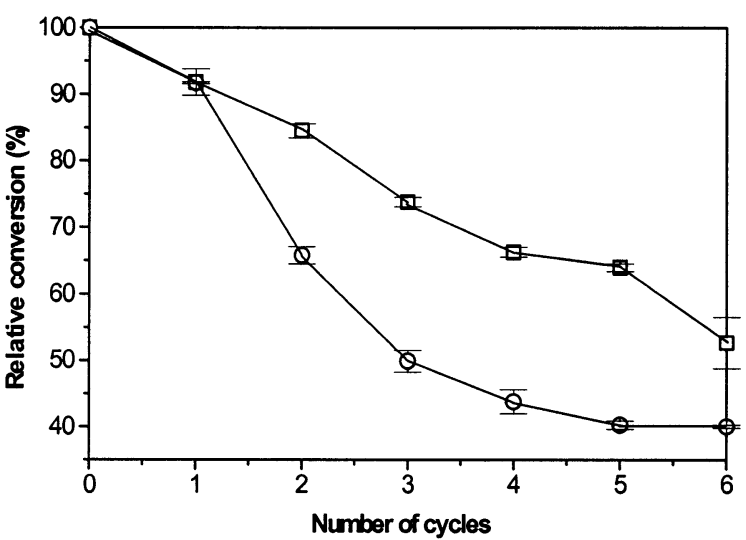

Figure 3. Effect of repeated uses of free $(O)$ and $S_{300} S_{A P T E S}$ immobilized ( $\square$ ) Proleather in the transesterification of sucrose with DVA at $45^{\circ} \mathrm{C}$, in DMF (av $\pm \mathrm{SD}, \mathrm{n}=3$ ). The starting conversion was taken as $100 \%$. One cycle corresponds to $12 \mathrm{~h}$ reaction time. The amount of active enzyme in the free and in the immobilized form was 2.17 and $1.39 \mathrm{mg}$, respectively.

free and $\mathrm{S}_{300} \mathrm{~S}_{\text {APTES }}$ immobilized Proleather improved the synthetic specific activity over ca. 5- and 4-fold, respectively (Figure 2). Above this level of hydration, the activity of the enzyme dropped precipitously for both preparations, presumably as a result of the dramatic increase in the DVA hydrolysis activity of Proleather. Interestingly, the immobilized and free Proleather preparations appear to respond identically to solvent hydration, suggesting that the silica carrier does not play a significant role in maintaining (or disturbing) enzyme hydration.

Reuse of I mmobilized Enzyme Preparations. The reusability of the enzyme is of considerable importance for industrial applications. The reusability of $\mathrm{S}_{300} \mathrm{~S}_{\text {APTES }}$ immobilized Proleather was investigated over six reaction cycles (corresponding to 3 days reaction time) in the sucrose acylation with DVA, during which ca. $45 \%$ reduction in the global reactivity of the enzymatic transformation occurred (Figure 3). Under the same operational conditions, using free enzyme, a higher reduction (ca. 60\%) in the conversion occurred. Therefore, higher stability may be achieved by the immobilization of Proleather onto silica supports. Furthermore, the stability of immobilized Proleather compares favorably to the results described in the literature for other enzymes in DMF. Carrea et al. (19) showed that the residual activity of protease $\mathrm{N}$ suspended in dry DMF at $45^{\circ} \mathrm{C}$ after 2 days was only $26 \%$.

\section{Conclusions}

We have identified Proleather to be an extremely effective sugar acylating catalyst in DMF. In the case of sucrose, the major product in the reaction with divinyladipate is sucrose 2-O-vinyladipate. This is a very interesting finding and represents the first demonstration of a secondary hydroxyl group acylation in a sugar without blocking of the primary hydroxyl groups. This selectivity was dependent on the organic solvent employed, thereby providing further evidence that the solvent has a significant impact on enzyme selectivity. In DMF, Proleather could be activated and stabilized by attaching to specific silica supports. I mmobilization of Proleather into $\mathrm{S}_{1000} \mathrm{~S}_{\text {APTES}}$-silica supports has allowed the synthetic activity to be greatly enhanced (10-fold) over that obtained for the native form. Furthermore, immobilized Proleather was more stable than free enzyme, retaining ca. 55\% activity after six reaction cycles.

\section{Acknowledgment}

Lino Ferreira would like to thank Dr. J ungbae Kim for very helpful discussions and the Fundação para a Ciência e a Tecnologia for financial support (Praxis XXI , BD/18456/98).

Supporting Information Available: ${ }^{1} \mathrm{H}-{ }^{1} \mathrm{H}$ COSY and ${ }^{1} \mathrm{H}-{ }^{13} \mathrm{C}$ HMQC NMR spectra of sucrose 2-O-vinyladipate. This material is available free of charge via the Internet at http:// pubs.acs.org.

\section{References and Notes}

(1) Wulff, G.; Schmid, J .; Venhoff, T. The synthesis of polymerizable vinyl sugars. Macromol. Chem. Phys. 1996, 197, 259274.

(2) Khan, R. Sucrose: Its potential as a raw material for food ingredients and for chemicals. In Sucrose Properties and applications; Mathlouth, M., Reiser, P., Eds; Blackie Academic \& Professional: London, 1995; pp 265-278.

(3) Ferreira, L.; Vidal, M. M.; Geraldes, C. F. G. C.; Gil, M. H. Preparation and characterization of gels based on sucrose modified with glycidyl methacrylate. Carbohydr. Polym. 2000, $41,15-24$.

(4) Therisod M, Klibanov AM. Facile enzymatic preparation of monoacylated sugars in pyridine. J . Am. Chem. Soc. 1986, $108,5638-5640$.

(5) Chen, X.; Dordick, J . S.; Rethwisch, D. G. Chemoenzymatic synthesis and characterization of poly $(\alpha$-methyl galactoside6-acrylate) hydrogels. M acromol ecules 1995, 28, 6014-6019.

(6) Martin, B. D.; Ampofo, S. A.; Linhardt, R. J .; Dordick, J . S. Biocatalytic synthesis of sugar-containing poly(acrylate)based hydrogels. Macromolecules 1992, 25, 7081-7085.

(7) Patil, D. R.; Dordick, J. S.; Rethwisch, D. G. Chemoenzymatic synthesis of novel sucrose-containing polymers. Macromolecules 1991, 24, 3462-3463.

(8) Patil, D. R.; Rethwisch, D. G.; Dordick, J. S. Enzymatic synthesis of sucrose-containing linear polyesters in anhydrous organic solvents. Bi otechnol. Bi oeng. 1991, 37, 639-646.

(9) Park, O.-J ., Kim, D.-Y.; Dordick, J. S. Enzyme-catalyzed synthesis of sugar-containing monomers and linear polymers. Biotechnol. Bioeng. 2000, 70, 208-216.

(10) Tweddell, R. J .; Kermasha, S.; Combes, D.; Marty, A. Immobilization of lipase from Rhizopus niveus: a way to enhance its synthetic activity in organic solvent. Biocatal. Biotransform. 1999, 16, 411-426.

(11) Ferrer, M.; Cruces, M. A.; Bernabé, M.; Ballesteros, A.; Plou, F. J . Lipase-catalyzed regiosel ective acylation of sucrose in two-solvent mixtures. Biotechnol. Bioeng. 1999, 65, 1016

(12) Matthijs, G.; Schacht, E. Comparative study of methodologies for obtaining $\beta$-glucosidase immobilized on dextranmodified silica. Enzyme Microb. Technol, 1996, 19, 601-605.

(13) Novick, S. J .; Dordick, J . S. Preparation of active and stable biocatalytic hydrogels for use in selective transformations. Chem. Mater. 1998, 10, 955-958.

(14) Ramos, M. A.; Gil, M. H.; Schacht, E.; Matthys, G.; Mondelaers, W.; Figueiredo, M. M. Physical and chemical characterisation of some silicas and silica derivatives. Powder Technol. 1998, 99, 79-85.

(15) Sedmak, J. J .; Grossberg, S. E. A rapid, sensitive, and versatile assay for protein using coomasie brilliant blue G250. Anal. Biochem 1977, 79, 544-552.

(16) Schonbaum, G. R.; Zerner, B.; Bender, M. L. The spectrophotometric determination of the operational normality of an $\alpha$-chymotrypsin solution. J . Biol. Chem. 1961, 236, 29302935.

(17) Riva, S.; Chopineau, J .; Kieboom, A. P. G.; Klibanov, A. $M$. Protease-catalyzed regioselective esterification of sugars and related compounds in anhydrous dimethylformamide. J . Am. Chem. Soc. 1988, 110, 584-589.

(18) Yoshimoto, K.; Itatan, Y.; Suda, Y. ${ }^{13} \mathrm{C}$ Nuclear Magnetic Resonance (NMR) spectra of O-acylglucoses. Additivity of shift parameters and is application to structure elucidations. Chem. Pharm. Bull. 1980, 28, 2065-2076. 
(19) Carrea, G.; Riva, S.; Secundo, F.; Danieli, B. Enzymatic synthesis of various 1'-O-sucrose and 1-O-fructose esters. J . Chem. Soc., Perkin Trans. 1 1989, 1057-1061.

(20) Soedjak, H. S.; Spradlin, J . E. Enzymatic transesterification of sugars in anhydrous pyridine. Biocatalysis 1994, 11, $241-248$

(21) Rich, J . O.; Bedell, B. A.; Dordick, J . S. Controlling enzyme catalyzed regiosel ectivity in sugar ester synthesis. Biotechnol. Bioeng. 1995, 45, 426-434.

(22) Kim, J . E.; Han, J . J .; Yoon, J . H.; Rhee, J . S. Effect of salt hydrate pair on lipase-catalyzed regi osel ective monoacylation of sucrose. Biotechnol. Bioeng. 1998, 57, 121-125.

(23) Oosterom, M. W.; Rantwijk, F.; Sheldon, R. A. Regioselective acylation of disaccharides in tert-butyl alcohol catalyzed by Candida Antarctica lipase. Biotechnol. Bioeng. 1996, 49, $328-333$.

(24) Therisod, M.; Klibanov, A. M. Regioselective acylation of secondary hydroxyl groups in sugars catalyzed by lipases in organic solvents. J. Am. Chem. Soc. 1987, 109, 3977-3981.

(25) Blanch, H. W.; Clark, D. S. In Biochemical Enginnering; Blanch, H. W., Clark, D. S., Eds; Marcel Dekker: New York, 1996; pp 103-148.
(26) Calculations of values of observable modulus $(\Phi)$ are based on a radius of the silica particles of 15 ( $\left.\mathrm{S}_{300} \mathrm{~S}_{\text {TESPM-pHEMA }}\right)$ and $14.5 \mu \mathrm{m}$ ( $\left.\mathrm{S}_{1000} \mathrm{~S}_{\text {TESPM-pHEMA }}\right)$, a bulk substrate concentration of $0.28 \mathrm{mM}$, and $\mathrm{D}_{\text {eff }}$ (for $\tau=7.0$ ) of $2.28 \times 10^{-7}$ $\left(\mathrm{S}_{300} \mathrm{~S}_{\text {TESPM-pHEMA }}\right)$ and $2.39 \times 10^{-7} \mathrm{~cm}^{2} \mathrm{~s}^{-1}\left(\mathrm{~S}_{1000} \mathrm{~S}_{\text {TESPM-pHEMA }}\right)$. The hindrance factor $(\mathrm{H})$ was not included in the calculations since the radius of the pore $(<170 \AA)$ is much greater than that of the solute molecule $(\cong 20 \AA$, considering that casein is a globular protein). Furthermore, the bulk diffusivity $\left(D_{s}\right)$ was calculated from the Stokes E instein equation (see ref 25) and was $2.1 \times 10^{-6} \mathrm{~cm}^{2} \mathrm{~s}^{-1}$.

(27) Fonseca, L. P.; Cardoso, J . P.; Cabral, J . M. S. I mmobilization studies of an industrial penicillin acylase preparation on a silica carrier. J . Chem. Technol. Biotechnol. 1993, 58, 27-37.

(28) Dordick, J. S. Designing enzymes for use in organic solvents. Biotechnol. Prog. 1992, 8, 259-267.

Accepted for publication J une 5, 2002.

BP0255457 